\title{
Parenting Patterns of Single Parents Father's Against Child Psychology
}

\author{
Hesti Meinawati ${ }^{* 1}$, Ni Made Wiasti ${ }^{2}$, Ni Luh Arjani ${ }^{3}$ \\ ${ }^{123}$ Anthropology Department, Faculty of Arts, Udayana University \\ ${ }^{1}$ hmeinawati@gmail.com, 르wiasti@yahoo.com, ${ }^{3}$ arjani_psw@yahoo.com \\ Denpasar, Bali, Indonesia \\ *Corresponding Author
}

\begin{abstract}
This study uses a qualitative method. The collection technique used is using observation, interviews, and literature study. The research problems were analyzed using StructuralFunctional Theory and Psychoanalytic Theory. The findings in this study are divided into two parts. First, the parenting pattern, the process of implementing the parenting style, the single parent Father takes care and educates the child by instilling values and norms, applying discipline, giving appreciation, providing religious education, meeting the physical needs of the child. In the process of parenting, there are obstacles and expectations of parents towards their children. Second, discussing the psychological implications for children, which can be seen in terms of children's moral behavior, children's personality and socialization, as well as children's play activities.
\end{abstract}

\section{Keywords: parenting, children, TKW, single parent, child psychological}

\section{INTRODUCTION}

Pratiwi (2017) explains that parenting is an educational style used by parents to guide and educate their children in the interaction process that aims to obtain the desired behavior. In this case, the role of parents is needed in the process of educating and guiding their children, so that the child can behave well.

The form of the family also influences in terms of parenting patterns, as well as the form of a family with single parents, which in the family single parents are people involved in parenting and childcare. Similarly, the family of migrant workers, which one or both parents departed to become Indonesian Workers abroad.
West Java Province is a contributor to many migrant workers in Indonesia. In 2019 data from the Indonesian Migrant Workers Protection Agency (BP2MI) West Java Province recorded as many as 5,010 people. One of them is Cirebon, West Java, which is a contributor to TKI. One of them is in Gembonganmekar Village, Babakan District, Cirebon Regency.

Some of the women in Gembonganmekar Village are no longer housewives, but instead become the family backbone of their livelihood by becoming Indonesian Female Workers, commonly referred to as TKW (Indonesian Female Worker). This is done to find additional family income. In addition to economic influence, TKW also has a socio- 
cultural influence on the family. The mother decides that becoming a TKW, will have an impact on the family that is left behind. The lack of one element of the family (wife/mother) can give an imbalance that affects the parenting style of a child falling on a father or a close relative such as a grandmother. Balance in the family can occur when there is a harmonious relationship, the interaction between father/husband and mother/wife, between father and child, and between mother and child occurs (Bahiroh, 2016).

Therefore, being a temporary single parent and playing multiple roles is not an easy thing for a man, especially in terms of educating children. This is because, on the one hand, a father must meet the psychological needs of the child, on the other hand, the father must also be able to meet the physical needs of the child.

Based on the background of the problems described, this study tries to examine the phenomenon of childcare patterns in TKW families in Gembonganmekar Village. The problem in this study is focused on (a) the pattern of caring for children in TKW families (b) psychological implications for children when the mother leaves work to become TKW abroad.

The location of this research is in Gembonganmekar Village, Babakan District, Cirebon Regency. The discovery of this location is based on several considerations including, because the profession of being a TKI (Indonesian Worker) in the village has become a commonplace thing among the people of Gembonganmekar Village and those whom to become TKI are dominated by women, who are referred to as TKW (Female Workers).

\section{METHOD}

This study uses a qualitative method. The collection technique used is using observation, interviews, and literature study. The research problems were analyzed using Structural-Functional Theory and Psychoanalysis Theory.

\section{RESULT}

\section{PARENTING PATTERNS ON TKW FAMILIES}

\section{a. Parenting Patterns}

Trisnawati (2019) parenting is the interaction of children with parents in terms of educating, guiding, disciplining, and protecting children to reach maturity according to the norms that exist in society.

Parenting patterns are the efforts and methods of every parent in terms of educating, caring for, and meeting all the needs of the child. Parenting patterns should be done by both parents, but because of the circumstances that require husbands to play a dual role in caring for children, on the one hand, the role of being a father, on the other hand, must be able to play a role as a mother. Caring is not only about physical needs but psychological needs are also one of the important things that caregivers must pay attention to, one example of love and attention from both parents.

Adawiah (2017) divides three types of parenting, including authoritarian parenting, permissive parenting, and democratic parenting. The parenting pattern applied by the father's single parent to his child is more inclined towards semi-permissive democratic parenting, which in the way of educating him is not too harsh and does not use punishment if the child makes a mistake. Children who make mistakes are only given 
advice or advice that this is not good, and there is no punishment to deter the child. This father's single-parent thinks that if he teaches his child too hard, his child will think that his father is fierce. Therefore, the father's single parent doesn't want his son to label his parents fierce. Husbands who raise children without the support of a wife make these husbands not want their children to be far away and not close to their fathers, therefore this father's single parent does not want to educate his children too hard and strictly.

\section{b. The Process of Implementing Parenting Patterns}

Social values are an attitude accepted by society, about what is right. While social norms are a set of rules that are expected to be adhered to and followed by the community in a particular social group. Rahman (2015) that the function of existing norms is like the most important element to maintain social relations in a social system can be carried out as expected.

In the family TKW, the father's singleparent teaches his child to always be polite to others, especially older people. Children are educated to be polite in behaving and polite in speech. Children are taught which language is good to talk about to older people and which language should only be spoken with peers, it is known as undak usuk basa which means manners in language.

According to Aulina (2013) discipline is something that includes teaching, guidance, or encouragement done by adults that aim to help children learn to live as social beings and to achieve optimal child growth and development.

Single parent father teaches his child to discipline on daily activities as well as, giving time to play and sleep. Children are used to disciplining in activities that are often done by children, such as playing. Single parent This father gives playtime to his son so that the child is used to discipline in using time. Single parent Father gives advice or reprimands if the child does not comply with and obey the existing rules. The purpose of this rebuke is to prevent the child from repeating it and to comply with the rules and get used to the rules.

Besides, single-parent fathers in Gembongamekar Village also apply methods of punishment and appreciation to children. The punishment given to the child is not physical but in the form of a reprimand or advice. The punishment is given when the child is disobedient to the parents, by scolding the child or giving a stern rebuke so that the child does not repeat. And then to giving awards, single parent Father's also gives awards to children when the child is obedient to parents.

Religious education is an important necessity for every religious people. Therefore, religious education has an important role in directing, reminding, and controlling religious people to always learn from the many teachings that must be understood and practiced as a provision to face the day of retaliation. In addition to inviting children to worship, a single-parent father also tries to educate his son to understand the religious values by still enrolling the child into the madrasah so that it can be smooth in recitation. Single parent father assumes that by putting his child into madrasah, making the child understands religious values and can implement religious values taught by being a devoted child to parents and have good morals.

In meeting the physical needs for his child, single parent Father is so indulgent his son, judging by the way father who always obeys whatever the child wants, from the 
need for pocket money that is never limited by single parent Father, because it feels a pity if given restrictions, however for food intake is not too thinking about 4 healthy 5 perfect, the most important thing for Dad is the food that his son likes. Furthermore, regarding the intake of vitamins, vitamins will be given by the single parent father when the child begins to feel unwell or when the child does not have an appetite.

c. The obstacle to the Implementation Process of Parenting Patterns

The process of implementing parenting patterns does not always go well and as expected. The process of implementing parenting patterns by single parents Father's there be found obstacles during the parenting process, it is natural if it occurs because of the parenting in the family tkw the absence of support and assistance from the spouse.

Fathers find it troublesome to take care of children when their children are sick because when the child is sick single parent Father's is also confused to take action. Because when the child is sick, the child is more likely to fuss about it that makes the father more panicked in taking action. Then the difficulty is also in terms of dividing time, between work time and parenting time. Single parent father who assumes two roles at once, makes Dad must be good at managing time, between to work and take care of his children. The division of time is, the morning father works and entrusts his son to the closest relatives as well as grandmothers or grandfathers. During work, his children were cared for by his closest relatives.

\section{d. Parents' Expectations of Their Children}

According to Lisanto (2020) expectations to realize possibilities and influence the goals achieved. In general, it can be concluded that hope is a positive mental state in a person with the ability he has to achieve future goals. As well as the expectations of parents, every parent wants their child to be better than him.

Single parent Father's wishes his children got a better fate than his parents, both in terms of economy, education, and personality of the child. Single parent father wants his children to be better successors and benefit the surrounding environment. Single parent Dad here looks so hopeful to his children to get a much better life than his parents. Every child from TKW family is expected to be a better person, to raise the level and dignity of the family.

\section{PSYCHOLOGICAL IMPLICATIONS FOR CHILDREN WHEN LEFT BEHIND MOTHERS DEPART TO BECOME MIGRANT WORKERS ABROAD}

\section{a. Psychological Implications for Children}

According to Qomariyanti (2017) that moral behavior is by the moral code of a particular social group. Moral behavior is controlled by moral concepts, the rules of conduct expected by all members of the group.

Single parent Father's efforts in making his child a moral child, therefore Father teaches his children to be polite when talking, especially talking to older people. Sometimes the child also speaks harshly when the child is angry, the harsh talk is more dominant coming from the external environment, as well as originating the surrounding environment, with peers, as well as the mass media. But the child who is fostered by a single-parent father is quite polite in interacting with his social environment.

Chairilsyah (2012) explains personality is the characteristic nature and behavior of a 
person who distinguishes it from others. Integration of characteristics of the structure from behavior patterns, interests, establishment, abilities, and potentials that a person has. Furthermore, about some personality models that exist in everyday life, among them, sanguine models, phlegmatic, melancholic, choleric, and assertive.

From the personality model, the personality owned by the child in the TKW family in Gembonganmekar Village is the personality of the sanguine model. In this sanguine model, the child looks excited when interacting with others and the child can also create a pleasant atmosphere for others when interacting with them. In the field, it appears that this TKW child can give a good impression when first meeting people, seen from his hospitality to the new person. The weakness of this personality model is that it is easily affected by the surrounding environment.

According to Muna (2016), selfadjustment (socialization) is one's ability to react effectively and harmoniously to social realities and social situations and can establish healthy social relations. Family is the first and foremost place for children to learn to socialize. Through the process of socialization in the family, children can learn how to interact and socialize in the wider community.

With the socialization ability of the children in the TKW family, researchers found that children in this TKW family socialize like children in the family in general. Children in this TKW family play and gather with their peers, just like children in general who play and gather according to their age, as well as playing marbles, online games, and gathering to do homework.

\section{b. Children's Play Activities To Children's Motor Development}

According to Elfiadi (2016), play is a term that is used freely so that its main meaning is lost. The most appropriate meaning is that every activity is done for the pleasure it causes, without risking the result. Play activities can be used by children to explore their world, develop children's creativity.

The child in the TKW family in Gembonganmekar Village is very happy to play with his peers outside the house. But there is a difference between boys and girls in choosing games. Boys used to play outdoors with their peers playing PS or online games. While girls are happy with more active games as well as playing chases, but there is no denying that girls are also happy to play gadgets more often.

Along with the development of the times cause traditional games that can encourage the motor development of children increasingly disappear. This causes the games that are in demand by children today in the form of online games, which will lead the child to become more personal because it is too focused on gadgets.

\section{CONCLUSION}

Parenting patterns applied by single parents to their children are more inclined to semi-permissive democratic parenting patterns, which in the way of educating them are not too harsh and do not use punishment if the child makes mistakes. The process of implementing parenting patterns, single parent Father parenting and educating the child in a way, instilling values and norms in the child as early as possible, applying discipline to the child such as giving playtime, giving appreciation to the child when the child is in contact with the parents, 
providing religious education by entering the child into the madrasah, meeting the physical needs of the child such as giving money snacks, clothing, food intake, as well as a decent place to stay. Obstacles to the process of implementing parenting patterns, when the child is not feeling well or sick. When the child is sick the child will be fussier, that's where a father will feel overwhelmed.

Psychological implications for the child when the mother left to work as a TKW abroad, can be seen in terms of moral behavior of the child, seen from the behavior of the child's manners when interacting with the surrounding environment, the personality of the child in the family TKW belongs to the category of sanguine model personality, where the child looks excited when interacting with others, socialization of the child in the family TKW can be said good, because the child can socialize with the surrounding environment well, children's play activities that can indirectly affect the attitude and behavior of the child.

\section{REFERENCE}

[1]. Adawiah, R. (2017). Parenting patterns and their implications for children's education: Study on Dayak Community in Halong Subdistrict, Balangan Regency. Journal of Citizenship Education, 7(1), 33-48.

[2]. Aulina, C. N. (2013). Apply discipline in early childhood. PEDAGOGIA: Journal of Education, 2(1), 36-49.

[3]. Bahiroh, A. F., \& Sumarwoto, V. D. (2016). Improving The Ability to Manage Emotions of Divorce Victims Assisted by Personal-Social Guidance With Simulation Techniques of Students of SMP Negeri 1 Takeran Magetan Regency. Counsellia: Journal of Guidance And Counseling, 4(2).

[4]. Chairilsyah, D. (2012). Positive personality formation of children from an early age. Educhild Journal: Education and Social, 1(1), 1-7.

[5]. Elfiadi, E. (2016). Play and Games For Early Childhood. ITQAN: Journal of Educational Sciences, 7(1), 51-60.

[6]. Lisanto, A., Andajani, S. J., \& Wahyudi, A. (2020). Children's Perception of Blind Parents' Parenting Patterns. JOURNAL ORTOPEDAGOGIA, 6(1), 50-61.

[7]. Muna, N. R. (2016). Patterns of Student SelfAdjustment In The Campus Environment. Edueksos: Journal of Social \&Economic Education, 1(2).

[8]. Pratiwi, K. I., \& Rustika, I. M. (2017). The role of authoritative parenting patterns and self-concept towards the social intelligence of early adolescents of
The State Junior High School in Denpasar. Udayana Journal of Psychology, 4(2), 448-459.

[9]. Qomariyanti, V. I. (2017). Revitalization of Folklore Through Cardboard Puppet Media as the Formation of Early Childhood Moral Values. Pedagogy: Early Childhood Journals And Early Childhood Education, 3(3a).

[10]. Rahman, E., Roslinda, E., \& Kartikawati, S. M. (2015). Social norms of nusapati villagers in the management of people's forests. Journal of Sustainable Forests, 4(2).

[11]. Trisnawati, W., \& Fauziah, P. (2019). Character Value Planting Through Refraction of Javanese Language in Early Childhood in Tanggeran Village, Banyumas Regency. Early Horizons: Journal of Early Childhood Education, 10(2), 93-100. 